\title{
INSIDE THE VIEWERS' MIND: THE EFFECTS OF MOVIES FEATURING TEACHERS IN REGARDS TO TEACHER'S ROLE AND ATTITUDE
}

\author{
Lilla Judit Lukács
}

\begin{abstract}
This paper investigates the link between media and the teacher image, with an outlook of critical understanding and pedagogy; it works with teacher-stories, with teacherroles, searching for the perceived difference between "good" and "bad" teachers in movies. The paper looks at how positive and negative movie clips are generating associations, experiences, and attitudes in the viewers generally, with the use of a questionnaire and screening of film episodes. The study is motivated by the assumption that media, and especially the "Hollywood Curriculum" sets up unrealistic expectations to the average person, portraying even radical ideas as liberating, or liberal. The research also looks further into the connection between the ethical dimensions in movies and the Hollywood curriculum. This includes analyzing the narrative basis of the teacher image in movies, leaving the question open in the end: how can we teach the next generation to use the media while being aware?
\end{abstract}

Keywords: movie pedagogy; film and media studies; critical pedagogy; narrative pedagogy; pedagogy debates; teacher's role.

\section{Introduction}

As the famous director Lars von Trier says: "A film has to be like a stone in the shoe." This article does nothing more than raising awareness based on a research project conducted on the point he has made in other words on the manipulative power of the media, with a pedagogical aspect.

When watching movies, the experience is intertwined with the experiencer's thoughts and narratives, yet the authentic storyline leaves only the final conclusion in our mind in the long run. Presumably, inspirational narratives live in the viewer further on, thanks to the so called ,sleeper effect" (Gillig and Greenwald, 1974), and they tend to affect our behavior, thoughts, and attitudes unconsciously later. The question is: are these "pop-up" methods linked to our minds, when we watch movies? And if the answer is yes, is it only the final conclusion of the story that gets planted, or are there other attitude-forming effects of which we are unaware? If yes, how is it linked to pedagogy?

The importance of critical thinking - especially in connection with media and pedagogy - is advocated since the nineteen-seventies by researchers such as Freire (1974) or Giroux 1997, 1994). It is important to emphasize that we must protect ourselves and our children from the possible media effects, especially in the age of mass-generated hoaxes or so called "fake news". Tyler Cowen (2009), one of the chief spokesmen of this viewpoint (since his TED performance [TED stands for Technology, 
Entertainment and Design conferences]), has said that we must brace ourselves from the most inspirational stories in the first place, because they, and their effects tend to last longer.

For me as an educator, these stories are the movies featuring teachers. Therefore, in my paper, I investigate the link between the media and teacher stories as they are represented in movies, with an outlook on teachers' role in them, searching for the perceived difference between good and bad teachers (from the viewers' side). I will look at how positive and negative movie clips generate associations, experiences, and attitudes in the viewers, with the use of a questionnaire, specially designed for this research. The preliminary assumption motivating the investigation is that media and especially the "Hollywood curriculum" has been argued to set up unrealistic expectations to the average person, portraying even radical ideas as liberating. (Dalton, 2004; Gerbner, 1972)

\section{Theoretical framework}

\subsection{Narratives and recipients}

If we become receptive of a movie and its storyline (and that is without a question), then one question arises: what makes us a successful, "good" recipient? The answer is trivial: if we "listen" to the story. We become receptive if we believe in what we hear (or from whom we hear it); and the more we emotionally engage while observing a story, the more we turn it into the story of ourselves, that is to say, we fall unintentionally into the state of a "good" recipient. (Bruner, 1991; Sikes, 2000)

However, it is important to stress out that this only works with a good, credible narrative. The same effect happens when people tell us stories - whether they are true or false. Sikes (2000) summarizes the peculiarities of lying: he found that the success of a lie is based on a good story: a story that captures the recipient and which is coherent, credible, uncomplicated and generates excitement and interest; also, it has to show the storyteller as the credible source. Sikes's argument is echoed by other scholars and intellectuals, too.

Don Levy in 2012 at a TED conference said that there is not a greater magic or illusion in the world than movies. With this belief he is not alone. Film analysts, directors and the honorary canon members of the film industry all have compared the world of films to magic, to illusion, and to dreams before (Morin, 1956; Bazin, 1965) from the very beginning. And indeed, if we interpret the concept of reality strictly, then movies are from a different world: whether they are lies or magic. Yet, we do mainly believe everything which is screened: the key to the screen's honesty and credibility paradoxically coincides with the key of its own lies - as I mentioned above „,[it] captures the recipient, [it] is coherent, credible, uncomplicated and generates excitement and interest; also, it has to light the storyteller as the credible source". Therefore, we may argue with considerable confidence that the basic elements of a movie correspond to Sikes's (2000) allegations of lies.

Ed S. Tan (1996, 2002), professor of communication and film analysis, also emphasizes the importance of excitement and interest while watching movies. His research area is the observation of the mechanism of emotions and experiences that emerge during watching movies and the question of the motivation to watch movies. To be specific, it is the following: why are we watching a movie? Why do we enjoy it? What does it take us to watch movies? He says that he might have found the answer for the mechanism: he assumes that the situation displayed on the moving picture, together with the narrative speech, creates an immediate and unconscious emotional response to a created fictional world. Thus, we get linked to the movie emotionally. 
What is unique in Tan's theory is that it is assumed that for the emerging emotional response (which we have been seen as a fundamental condition for reception before: it is acceptance) we should be interested in the film (and interest is directly related to the narrative speech in his theory). He says that in the most "fortunate" case - because of our interests - we also grow to love the picture on the screen. Therefore, on the long run, the two components of motivation (interest and liking) will give the basis for the upcoming emotional responses and attitudes, generated by the movie. In contrast, one of the debate partners of Tan; Carl Plantinga, in 2001, stated that any sudden emotion (not just interest and liking) what the film brings to us, is enough to link us to the movie emotionally and make us identify with the film; this is part of the so-called "assimilation effect".

Whatever is the correct answer behind the mechanism, they agree that the liking of the film or feeling excitement during the screening will make us identify with the movie, and with the experience. However, even the everyday language knows this somehow. We call it "Hollywood claptrap", and this is the factor that keeps the evolution of the film industry going at the moment (which is not the same as the "news industry"). The movie industry is eager to get more people interested in cinema, as it is a clear sign of success and money. Yet, we do not realize what it means. It means that the film production has won a fight which is not even conscious, but in which the stakes are the minds of consumers.

\subsection{The perception of the "good" teacher in movies}

Weber and Mitchell (1995) - based on their researches - state that the average person's views when it comes to teachers can be strongly shaped by how the pop culture treats the general teacher image. However, there are more trends in the interpretation of the fictional teacher's image.

Farrell (1970) basically approaches the interpretation of teachers' images from the point of view of the characters. In his model, he found ten types of teachers in movies - and each type is coming with a "shadow" function. The ten types and the functions are the following:

The Birch-cane Image - Linked with revolutionary values;

The Governess Image - Can be linked to democratic values;

The Anne-of-Green-Gables Image - Can be linked to the feeling of nostalgia;

The Dominie Image - Can be linked to deterrence from autocracy;

The Gloud-Guckoo-Land Image - Can be linked to the great truths of life;

The Puff-Spot Image - Can be linked to the female feminist heroine of Hollywood, and with the "everything for the children" minded mothers.

The Milquetoast Man - Can be linked with the typical anti-hero who is there to be avenged during the coming-of-age stories.

The Ghetto Image - Can be linked to the idea of equal opportunities,

The Robot Image - Who are there to transfer the idea of the right system,

The Prima Donna Image - Can be linked to the image of the self-confessing teacher. 
"Shadow" functions are always having a sense or a goal. For example: „The Anne-of-Green-Gables" type of narrator or teacher aims at the promotion of the nostalgic atmosphere in the viewers. On the other hand, "Birch-cane Image" teachers (for example, Mr. Keating from the Dead Poets Society) generally teach only boys and they are the instruments of transmitting (mostly revolutionary) values, and so on.

However, Farrell (1970) did not design his characterization to be interpreted only in filmmaking (he also aimed for literature, for example), therefore after a few years his ideas became old-fashioned, and new theories were born: theories what work better when it comes to strictly interpret movies.

The trend closest to Farrell's tenets was the model of archetypes (Antalfai, n.d.) originally created by Jung, but only interpreted in filmmaking in the late 70's. Based on Jung's work of personalities (Antalfai, n.d.), researchers have found the age-old archetypes behind the movie characters (such us, the Mentor, the Hero, the Shadow, etc.). In these interpretations, teachers who have reached a great deal in their environment (or within themselves) can usually be traced back to a synonym of the Savior, or the Wise Old Man, or they even fit into the role of a Divinity; while those teachers who are the harmful ones are generally the interpretation of the Devil, the Shadow, or the Unconscious. (Király, 1998, Voytilla, 1999).

On the other hand, analysts representing critical pedagogical approaches, such as Giroux (1988), Kellner (2005), Gerbner (1972), Beyerback (n.d.) and Dalton (2004), prefer a framework of interpretation in connection with the hidden curriculum and social problems. In Beyerback's database, which contains fifty-five films we find that the teachers in the vast majority of American films are white, middle-class men - although by the passing of time it can also be observed that the image of the teacher in films is going through the process of feminization.

In the research presented in this paper, I approach the problem from the point of view of critical pedagogy. In connection to this, Mary M. Dalton, in 2004, in her book called „The Hollywood Curriculum" cites Huebner (1975, as cited by Dalton, 2004). By this citing she refers to the five framework-values for defining the hidden curriculum, which are the following: the technical factor (interpreting the question of equipment, for example), the scientific factor (interpreting, for example, the knowledge of the teacher), the aesthetic factor (interpreting the classroom or the external appearance of a teacher), the political factor (interpreted as revealing hidden social structures), and ultimately, the ethical factor (for more details in the next subsection). Dalton uses all of these factors in her narrative film analysis (with Hollywood movies featuring teachers) while searching for answer to the following question: what makes someone a "good" teacher when it comes to the Hollywood curriculum?

Later on, in her book, she answers that question with the following statements, based on her narrative analyses. To be a good teacher in the Hollywood framework, one has to have the following abilities:

the good teachers in the movies are individuals;

often outsiders;

they often appear as new teachers in the life of a community;

they are personally joining in, and getting involved in the class' life as a community and as an individual; 
they are not afraid to learn from their students, and they are ready to change;

they are advocates for their students, or at least they go against the school's preexisting practices when it is needed;

they work with a specific curriculum, even if it is weird or odd;

they are not afraid to show that they really care about their students;

their cooperation with students is often progressive: at the end of the film/story, a challenge or a spiritual journey ends.

Of course, these are questioning the true ethics of the Hollywood curriculum (are these teachers really good?), but the method works. A remarkable example can be made by the Dead Poets Society, which movie has been analyzed by a number of intellectuals who believe in critical pedagogy. Since Mr. Keating is often set as "the alpha and the omega" of a good teacher, he has been analyzed from that point many times (Kellner, (2005), Giroux (1993), Heilman, (1991) Dalton, (2004)). The point of researchers is interesting: even though that Mr. Keating seems to be using really weird, performative, subversive, and conveying methods, we cannot be sure about his work as a teacher, leave alone his ethics. Using analysis, questions are rising: was he really ethical to leave his students behind in such a tragedy? Did he act ethically correct towards his colleagues? Did he really teach his disciples to revolt against the idea of autocracy, or did he suggest a white, middle-class man's point of view while reciting classical literature? The questions are suggesting that analysts' answer is „no,” and indeed, Keating's education techniques differ widely from what we would actually call a "good teacher" in reality. But how can the effect of the film in us be infinitely positive, awakening the image of a teacher who is already perfect?

\section{Research Methods and Data Analysis}

\subsection{Research questions and hypotheses}

This paper is intended to answer the question, whether teachers appearing in motion pictures influence the expectations, thoughts, preconceptions, feelings, attitudes or even memories of a mixed, nonhomogeneous (yet not representative) sample, targeting the population. The research approaches this question from two points of view, with two different hypotheses, described below.

The first hypothesis (1/a) aims to find out if the good and the bad teachers - ranked by Huebner's (1975) and Dalton's (2004) ethical categories - are distinguishable by perceiving their attitude by the viewer, thus validating this categorization method. Secondly, it was observed how the experiencer's previous teacher experiences are affecting this perception (1/b hypothesis), and at the end, the research looked deeper into, how the type of the movie clip(s) and the previous experiences differentiate the number of own memories (second hypothesis) brought up by the participants, therefore it is connected to the above mentioned "sleeper effect". The results are described below.

\subsection{Methodological Background and Data Analysis}

Data was gathered with the help of an online, self-created questionnaire (Cronbach alpha varies from $0.72-0.80$ throughout the sections in which Likert-scales were used to measure the reliability). The questionnaire on teachers in movies and their ethical roles consisted of seventy-five items, of which 10 
were open questions and 5 were there for the demographic data of the sample (gender, age, education, occupation, place of residence). Therefore the questionnaire contained both open and closed questions. Closed questions were used to assess the attitudes. Thus, the questionnaire contains a larger number of Likert-scales (ranging from 1-5, where 5 disagrees the most, to avoid routine replies), and an Osgood semantic differential scale (1-7 in which 7 is the end of the disagreement). The work of Judith N. Thelen (1971) and Moradi et al. (2011) was used as an example in the compilation of the scales; also, I have taken into consideration - while creating the scales - Fodor's (2000) and Dalton's (2004) "good and bad teachers" lists. The questionnaire contained videos as well.

After completing the questions about the demographics and school experiences/attitudes (E.g. did you like to go to school at that time, etc.), the questionnaire breaks down into two parts, by choosing a random number (1-6). Sympathy-based choice of numbers ensured the absolute random grouping. The two groups watched videos featuring teachers from ethically different dimensions (videos of good and bad teachers); in both cases, there were four videos. The total time of screening took 17 and 18 minutes in the two groups. The ethical dimensions were based on Mary. M. Dalton's (2004) theory, whose ethical classification reached back to the ethical dimension of the five framework values of Huebner, presented above (1975, cited by Dalton, 2004).

Taking these requirements into consideration, I have opted for - in a necessarily subjective way - the following films (though I had criterions also, described below). In the dimensions of the good teachers: Dead Poets Society (1989), Monsieur Lazhar (2011), Sister Act 2 (1993), Les Choristes (2004). In the bad teacher's dimensions: Bad Teacher (2011), Monsieur Lazhar (2011), Die Welle (2008), Battle Royale 2 (2003).

In the case of the "good teacher" videos, it was a criterion to stand for all of the outlines of Dalton (2004) (that is, to conform to the ethically ideal Hollywood teacher image in Dalton's interpretation); and I also made several criterions for the different characters in this section (like: at least one woman by category; different physical properties, etc.). Though, the differentiation in the characters was also a required dimension of the "bad teachers"; yet the basic requirement for this category was not just a visual representation of Dalton's (2004) framework, but I also made a criterion to show at least one of the characters act out - during the video montages - in a pedagogically exaggerating way, at least once (in most of the cases it was physical aggression). This was necessary because, in the case of short films, there has been a worrying possibility about the judgment; that it might not be so clear if there were a lack of proper interaction - although the interpretation does not recognize a neutral value judgment in the questionnaire. For these reasons, I have put the age limit for filling the form at 18 - and also created an information page because of the research's ethic reasons.

Also, when choosing films, I took three more aspects into consideration: in both categories, there is once a video where the teachers' relationship with the colleagues is displayed (good teacher: Les Choristes, bad teacher: Bad Teacher). Both of these categories include two videos, which were not made in an American film studio, yet the visuals are following the "Hollywood theme": (good teacher/bad teacher: Monsieur Lazhar - French; good teacher: Les Choristes - French; bad teacher: Battle Royale 2 Japanese). Also, there is a movie which is presented for both categories (Monsieur Lazhar).

In the questionnaire, the responders had eight Osgood scales for each of the videos; every time it contained different pairs of attributes about the teacher in the video. The scales covered the characteristics, but also the methods and the nature of the teaching process. After each video, the recipient had to decide how realistic the teacher was, and he or she also had to respond to the question 
whether he or she associates to a teacher (he or she knew before) thanks to the videos. The last phase of the questionnaire was an attitude questionnaire evaluating the videos altogether, containing nine items. Here, responders had to agree on a variety of statements on 1-5 scale scales (for example: I would like to enroll my child to a school where such teachers teach, etc).

Later on, the data analysis was made with SPSS 20.0 and with Microsoft Excel.

\subsection{Participants}

The sampling was done by combining the comfort sampling method and the snowball method, since the research did not aim for a specific group, but for people in general. Although the sample is not specified, it is not representative of the population due to the method of sampling. The online self-filled questionnaire was posted on a social media website where people were asked to share it. I informed the participants in the introduction of the research that the research is about examining the role of teachers' and the movie experiences, and that it is ensured that the records are anonymous.

The sample contains 117 responders $(n=117)$. Looking at the answers of the responders: $61.54 \%$ are women, their average age is 25.5 (with the deviation of 6.089 years), and $68 \%$ of the responders are living in Budapest (capital of Hungary). Most of them are either still learning (47\%) or they are working as an employee (33.3\%). 44.4 percent of the sample have finished their studies with the maturity exam, but also $39 \%$ also holds a BA degree. In average the responders have left school 2.5 years ago (deviation: 4.6 years). Also, $57.3 \%$ of the responders liked to go to school (when it was their time), and 58\% of them has some kind of memory with a teacher what have formed them to be a better person (which is a factor to remember when looking at the results).

\section{Results and discussion}

In the following section I will present my findings in regards to the hypotheses.

To test the first hypothesis (which is connected to the ethical dimensions of the above mentioned theory), an Independent Sampled T-Test was used. As Levene's Standard Deviation Homogeneity Test was significant $(\mathrm{F}=8.82, \mathrm{p}<0.004)$, therefore, the variance of the two samples differed, considered the robust version of the T-test was considered; the so-called Welch d-test. According to this, there is a significant difference between the good and bad teachers in movies, based on the viewing groups [t $(94$, $887)=-20,512, p<0,001)]$. The viewers are significantly differing in their attitudes reflecting on the teachers involved in the movies: based on descriptive statistics, those who have seen good teachers on the videos were more positive about the video on teachers than those who saw bad teachers. These results were also aligned with the results of the Osgood scales. Therefore the present data seems to justify the first hypothesis, and with this I could test Dalton's theory in practice for the first time. This result means two things:

Dalton's framework - which has never been tested in a quantitative work - has been proved right, in the ethical dimensions. Since it was stated that her dimensions are based on the framework of the hidden curriculum, it is safe to say, that the classroom hidden curriculum is observable even in the moving picture's screen, and not just for scientists.

The results also show that the films indeed affect our mood and attitudes towards the topic of the movie, therefore the mechanism which was presented above - in the literal part - is working. Yet it was in 
question whether we can differentiate between movies and real life - or after watching a movie our viewpoints, feeling, thoughts are heavily altered.

Therefore, the research also has aimed to test to connection in between associations/memories and movies, so the second part of the hypothesis was tested the following way: a multi-variance analysis was used, in which the independent variables were the nature of the videos and the previous teacher experiences. The dependent variable was the cumulative positive attitude score that applied to teachers on the movies, based on the answers. Based on the ANOVA, the type of the video which have been viewed has the main effect $[\mathrm{F}(1)=201,937, \mathrm{p}<0.001)]$. Neither the nature of the previous experience with teachers $[\mathrm{F}(7,012)=0,373, \mathrm{p}=0,690]$ nor the interaction between the type of the video and the previous teacher's experience $[\mathrm{F}(2)=0,046, \mathrm{p}=0.955)]$ have a significant effect on attitudes. This hypothesis thus cannot be justified by the current data.

Therefore, in regards to the first hypothesis the results the analysis altogether showed that Dalton's grouping method (2004) works: the attitudes were significantly worse with the bad teachers' clips, but I could not prove that this effect would be paired up and strengthened by the previous teacher experiences, or memories; nor could I link it to the actual engagement to those. Which means engagement could occur while watching a movie without making any connection to one's personal life, yet I wonder - if I had found someone who is deeply affected by this topic, would their results show a different kind of engagement?

As for the second hypothesis, I got mixed results.

Testing Hypothesis 2/a was also performed using several variance analysis variables; in which the independent variables, like in the previous ones, were the videos being watched and the nature of the previous teacher experiences, and the dependent variable was the number of memories that have appeared during watching the movies. When it comes to the number of appearing associations the character of the previous teachers' experiences had the significant main effect $[(F(2)=3.845, p=0.24)]$. Also, there is a trend-level effect on the interaction between the type of film being viewed and the previous teachers' experiences $[\mathrm{F}(2)=2.966, \mathrm{p}=0.56)]$. These two make a differentiation on those who have watched different or the same kind of movies from their previous experiences. This states, that even though when it comes to the number of associations the character of the previous teachers' experiences will determinate it; yet the movie and the experience might strengthen each other. This aligns with the following findings:

When looking at the correlations from the side of one's personal experiences with teachers: on the basis of the more detailed comparisons, those who have neutral previous teacher experiences tend to have less association with the films than those who have a negative previous teacher image $(p=0.079)$ and have significantly less association than those who have positive $(\mathrm{p}=0.009)$ previous teacher experiences. However, this relationship is only true to those who have seen a good video of a teacher. None of the other groupings gave positive results.

When looking at the correlations from the side of the type of the movies: based on the data, in the case of the hypothesis, the Levene's Standard Deviation Homogeneity Test became significant $(\mathrm{F}=12,174$, $\mathrm{p}$ <0.001). Based on this, the Welch d-test had been used to compare the two groups, but it was not significant $(\mathrm{t}(52.1)=1.609, \mathrm{p}=114)$. Which means that the good and bad teacher video-viewers did not differ (altogether) in how much their own experience came to mind about the videos later on. 
Therefore we can say that the number memories and associations depend on the previous experiences, not on the type of the movie (they do not have to align when it comes to the feeling or the topic), yet they might strengthen each other in some special cases (see the trend-level indicators). But putting aside these, it is safe to say - based on the results - that movies do not need a previous personal involvement to reach attitude, thought and mood affecting engagement (probably without questioning their narratives in a topic - but that is a research question for the follow-up work).

\section{Summary}

Even though the current data does not provide evidence for every hypothesis presented, the research has reached several new results. First, it was able to test and prove Dalton's theory about the ethical framework of the Hollywood curriculum for the first time. And second: it showed by the date - while searching for the "sleeper effect" that those who have good memories of teachers and schools are more likely to remember and associate their memories and feelings when they got a positive impulse, compared to those who are having neutral memories. This raises several questions about those who are having neutral/good memories and experiences (a bit more than half of the sample): why is it only observable during the "good" videos? Do we like to feel nostalgia that much? Why is it so hard to reach those (even compared to those who have bad memories of teachers) who are seeing themselves as having neutral memories? And how can we interpret the lack of answers and associations when it comes to negative teacher figures in movies? The questions that occur are not just pedagogical and psychological, but they affect the schooling system as a whole: should we believe that there are no associations when it comes to movies featuring bad teachers? If yes, why they are observable when a positive example is shown - expect the neutrals? What are those things, which are unfolded here; what are those memories that are sleeping, and cannot be awakened (not even by such manipulative terms, like movies), and how does this affect the society's response and thoughts on schooling in general?

Also, when it comes to movies and pedagogy - are we fully aware, that screening itself, will determinate engagement, without any restrictions from one's persona? Are we ready to use such a manipulative and robust tool in our classrooms with being able to say we know what we expect at the end? If yes, how?

We should hear and listen to those voices which have been raising awareness to the lack of film narratives in education. Such as, Mészáros in 2005 states that schools (in general) cannot avoid the dialogue between the pedagogy and the narrative interpretation of movies, which are shaping us and our youth. (Mészáros, 2005) Since I do believe that school cannot, and should not leave the world and its achievements (like films) outside, it might be time to tame the beast of the media into the school's repertoire. But this needs much more research on question like, what have been raised above. Hopefully, such researches are going to be conducted in the future.

\section{Bibliography}

Antalfai, M. (2007): Személyiség és archetípusok Jung analítikus pszichológiájában. In: Gyöngyösiné Kiss E., Oláh A. (ed.): Vázlatok a személyiségről - A személyiséglélektan alapvető irányzatainak tükrében. Új Mandátum Kiadó, Budapest, http://www.antalfaimarta.hu/olvashato\%20irodalom/jung.pdf.

Bazin, A. (1965): Korunk nyelve. In: Zalán V. (ed.): Mi a film? Osiris Kiadó, Budapest. 7-15. 
Beyerback, B (n. d.): Representations of Teachers in 60 Years of Films: A Database promoting Critical Analysis of Teacher Image with regard to Race, Class, and Gender. link: http://www.oswego.edu/ beyerbac/representations_of_teachers_in_6.html.

Bruner, J. (1991): The narrative construction of reality. Critical Inquiry 18:1-21.

Cowen, T. (2009): Be suspicious of stories, TEDxMidAtlantic $11 . \quad$ link: http://www.ted.com/talks/tyler_cowen_be_suspicious_of_stories.html.

Dalton, M. M. (2004): The Hollywood Curriculum: Teachers in the Movies. P. Lang, California

Don Levy (2012): A cinematic journey through visual effects, TEDTalks, link: http://www.youtube.com/watch?v=H4iRPytrnJo

Farrell, J. (1970): The teacher image in fiction. Winnipeg, link: http://mje.mcgill.ca/index.php/MJE/article/view/6718/4663

Freire, P. (1974): Pedagogy of the Opressed. The Seabury Press, New York.

Fodor, G. (2000): Tanár - szerep - konfliktusok. Gondolatok a tanár-diák viszony mítoszairól. Új Pedagógiai Szemle, 2. sz. 66-75.

Gerbner, G. (1972): Teacher image and the hidden curriculum. The American Scholar, link: http://www.asc.upenn.edu/gerbner/Asset.aspx?assetID=2033

Gillig, P.M., és Greenwald, A.G. (1974): Is it Time to Lay the Sleeper Effect to Rest? Journal of Personality and Social Psychology, 29. 1. ed. 132-139.

Giroux, H. (1997): Channel Surfing: Racism, the Media, and the Destruction of Today's Youth. London and New York, Routledge.

Giroux, H. (1994): Disturbing Pleasures. Learning Popular Culture. London and New York, Routledge.

Giroux, H. (1988): Schooling and the Struggle for Public Life. Critical Pedagogy in the Modern Age. University of Minnesota Press, Minneapolis.

Kellner, D. (2005). Critical Pedagogy, Cultural Studies, and Radical Democracy at the Turn of the Millennium: Reflections on the Work of Henry Giroux. link: http://www.gseis.ucla.edu/faculty/kellner/kellner.html.

Király, J. (1998): Mágikus mozi. Múfajok, mítoszok, archetípusok a filmkultúrában. Korona kiadó, Budapest.

Mészáros, Gy. (2005): Kortárs filmek fiatalságképe. In: Iskolakultúra, 10. sz. 84 - 96. p.

Moradi és et al (2011): The Effect(s) of Culturally Motivational Films on the Attitude of Iranian Students. Theory and Practice in Language Studies, 1. 12. ed. 1843-1848.

Morin, E (1956): Az ember és a mozi (részletek) In: Gelencsér, G. (ed.): Mozgóképkultúra és médiaismeret szöveggyüjtemény. 
Plantinga, C (2001): Desire, Interest, and the Search for Global Affect Structure in Film. Calvin College. link: http://www.avila.edu/journal/vol4/plantinga_tan_jmis_def.pdf

Robert B. Heilman (1991): The Great-Teacher Myth. American Scholar, 60. 3. sz. 417 - 423.

Sikes, P. (2000): Truth and Lies Revisited. British Educational Research Journal, 26. 2. sz. 257 - 270.

Tan, E. (1996): Emotion and the structure of narrative film: Film as an emotion machine. NJ: Lawrence Erlbaum Associates, Mahwah.

Tan, E. S. (2002): Interest as Global Affect Motivation in film: A reply to Carl Plantinga Vrije Universiteit Amsterdam. link: http://www.avila.edu/journal/vol4/plantinga_tan_jmis_def.pdf.

Thelen, N. J. (1971): Constructing an attitude scale for motion pictures, N.J., Educational Technology Publ., cop, Englewood Cliffs.

Voytilla, S. (1999): Myth \& the Movies: Discovering the Myth Structure of 50 Unforgettable Films. Michael Wiese Productions, California.

Weber, S. és Mitchell, C. (1995): That's Funny, You Don't Look Like a Teacher. The Falmer Press, Washington D.C.

\section{Author}

Lilla Judit Lukács, Doctoral School of Education, Eötvös Loránd University, Institute of Education, Eötvös Loránd University, Budapest (Hungary). E-mail: lillajuditlukacs@ gmail.com 
